Atmos. Chem. Phys., 10, 6283-6294, 2010

www.atmos-chem-phys.net/10/6283/2010/

doi:10.5194/acp-10-6283-2010

(C) Author(s) 2010. CC Attribution 3.0 License.

\title{
Measurement of atmospheric nitrous acid at Bodgett Forest during BEARPEX2007
}

\author{
X. $\operatorname{Ren}^{1}$, H. Gao ${ }^{2}$, X. Zhou ${ }^{2,3}$, J. D. Crounse ${ }^{4}$, P. O. Wennberg ${ }^{5,6}$, E. C. Browne ${ }^{7}$, B. W. LaFranchi ${ }^{7, *}$, R. C. Cohen ${ }^{7,8}$, \\ M. McKay ${ }^{9, * *}$, A. H. Goldstein ${ }^{9}$, and J. Mao ${ }^{10, * * *}$ \\ ${ }^{1}$ Rosenstiel School of Marine and Atmospheric Science, University of Miami, Miami, FL, USA \\ ${ }^{2}$ Department of Environmental Health Sciences, State University of New York at Albany, Albany, NY, USA \\ ${ }^{3}$ Wadsworth Center, New York State Department of Health, Albany, NY, USA \\ ${ }^{4}$ Division of Chemistry and Chemical Engineering, California Institute of Technology, Pasadena, CA, USA \\ ${ }^{5}$ Division of Engineering and Applied Sciences, California Institute of Technology, Pasadena, CA, USA \\ ${ }^{6}$ Division of Geological and Planetary Sciences, California Institute of Technology, Pasadena, CA, USA \\ ${ }^{7}$ Department of Chemistry, University of California at Berkeley, Berkeley, CA, USA \\ ${ }^{8}$ Department of Earth and Planetary Science, University of California at Berkeley, Berkeley, CA, USA \\ ${ }^{9}$ Department of Environmental Science, Policy, and Management, University of California at Berkeley, Berkeley, CA, USA \\ ${ }^{10}$ Department of Meteorology, Pennsylvania State University, University Park, PA, USA \\ *now at: Center for Accelerator Mass Spectrometry, Lawrence Livermore National Laboratory, Livermore, CA, USA \\ **now at: California Air Resources Board, Sacramento, CA, USA \\ *** now at: School of Engineering and Applied Sciences, Harvard University, Cambridge, MA, USA
}

Received: 11 March 2010 - Published in Atmos. Chem. Phys. Discuss.: 22 March 2010

Revised: 27 June 2010 - Accepted: 5 July 2010 - Published: 12 July 2010

\begin{abstract}
Nitrous acid (HONO) is an important precursor of the hydroxyl radical $(\mathrm{OH})$ in the lower troposphere. Understanding HONO chemistry, particularly its sources and contribution to $\mathrm{HO}_{\mathrm{x}}\left(=\mathrm{OH}+\mathrm{HO}_{2}\right)$ production, is very important for understanding atmospheric oxidation processes. A highly sensitive instrument for detecting atmospheric HONO based on wet chemistry followed by liquid waveguide long path absorption photometry was deployed in the Biosphere Effects on Aerosols and Photochemistry Experiment (BEARPEX) at Blodgett Forest, California in late summer 2007. The median diurnal variation shows minimum HONO levels of about 20 30 pptv during the day and maximum levels of about 60 70 pptv at night, a diurnal pattern quite different from the results at various other forested sites. Measured $\mathrm{HONO} / \mathrm{NO}_{2}$ ratios for a 24 -h period ranged from 0.05 to 0.13 with a mean ratio of 0.07. Speciation of reactive nitrogen compounds $\left(\mathrm{NO}_{\mathrm{y}}\right)$ indicates that HONO accounted for only $\sim 3 \%$ of total $\mathrm{NO}_{\mathrm{y}}$. However, due to the fast HONO loss through pho-
\end{abstract}

tolysis, a strong HONO source $\left(1.59 \mathrm{ppbv}^{\mathrm{day}}{ }^{-1}\right)$ existed in this environment in order to sustain the observed HONO levels, indicating the significant role of $\mathrm{HONO}$ in $\mathrm{NO}_{\mathrm{y}}$ cycling. The wet chemistry HONO measurements were compared to the HONO measurements made with a Chemical Ionization Mass Spectrometer (CIMS) over a three-day period. Good agreement was obtained between the measurements from the two different techniques. Using the expansive suite of photochemical and meteorological measurements, the contribution of $\mathrm{HONO}$ photolysis to $\mathrm{HO}_{\mathrm{x}}$ budget was calculated to be relatively small (6\%) compared to results from other forested sites. The lower HONO mixing ratio and thus its smaller contribution to $\mathrm{HO}_{\mathrm{x}}$ production are attributed to the unique meteorological conditions and low acid precipitation at Blodgett Forest. Further studies of HONO in this kind of environment are needed to test this hypothesis and to improve our understanding of atmospheric oxidation and nitrogen budget.

\section{Correspondence to: $\mathrm{X}$. Ren}

(xren@rsmas.miami.edu) 


\section{Introduction}

Nitrous acid (HONO) plays an important role in atmospheric chemistry because its photolysis results in the formation of the hydroxyl $(\mathrm{OH})$ radical, the key atmospheric oxidant that initiates the oxidation of many primary and secondary pollutants leading to the formation of ozone and fine particles. Previous studies have found HONO photolysis to be a major or an important $\mathrm{OH}$ source in forested (Winer and Biermann, 1994; Harrison et al., 1996; Alicke et al., 2003, 2006a; Kleffmann et al., 2005; Ren et al., 2006) and urban environments (Alicke et al., 2003; Ren et al., 2003; Acker et al., 2006a; Mao et al., 2010). Measurement of HONO within these environments can reveal the contribution of HONO photolysis to $\mathrm{HO}_{\mathrm{x}}\left(=\mathrm{OH}+\mathrm{HO}_{2}\right)$ radical production and oxidation capacity. Furthermore, recent studies have demonstrated that the photolysis of $\mathrm{HONO}$ is an important $\mathrm{OH}$ source, not only in the early morning when other $\mathrm{OH}$ sources (such as the photolysis of $\mathrm{O}_{3}$ ) are still small, but also throughout the day. This indicates the existence of a strong daytime $\mathrm{OH}$ source from HONO photolysis. In these studies, the contribution of HONO photolysis to $\mathrm{HO}_{\mathrm{x}}$ production was often found to be greater than or comparable to the contribution from the photolysis of ozone and formaldehyde (Neftel et al., 1996; Staffelbach et al., 1997; Zhou et al., 2002a; Kleffmann et al., 2003, 2005, 2006; Vogel et al., 2003; Acker et al., 2006b, 2007; Ren et al., 2003, 2006; Elshorbany et al., 2009; Mao et al., 2010).

Despite the importance of HONO in atmospheric chemistry, HONO source strengths and its detailed formation mechanisms, especially during daytime, are not well understood. In addition to the homogeneous HONO formation from the reaction of $\mathrm{NO}$ with $\mathrm{OH}, \mathrm{Li}$ et al. (2008) found that the reaction of photolytically excited $\mathrm{NO}_{2}$ with water can form $\mathrm{HONO}$ and $\mathrm{OH}$, but its reaction rate and yield are still under debate (Carr et al., 2009) and this mechanism likely contributes insignificantly to atmospheric HONO formation. Models taking into account only the homogeneous HONO sources typically predict significantly lower HONO concentrations than measurements. Heterogeneous processes are thus considered as major HONO sources, along with the homogeneous formation and direct emissions from combustion processes. Major heterogeneous processes to form $\mathrm{HONO}$ include: (1) heterogeneous conversion of $\mathrm{NO}_{2}$ adsorbed on humid surfaces (Ammann et al., 1998; Finlayson-Pitts et al., 2003; Ndour et al., 2008); (2) photosensitized reduction of $\mathrm{NO}_{2}$ on organic surfaces such as aromatics and humic acids (George et al., 2005; Stemmler et al., 2006; Qin et al., 2009), and (3) photolysis of surface adsorbed nitric acid $\left(\mathrm{HNO}_{3}\right)$ and nitrate (Zhou et al., 2001, 2002b, 2003). Heterogeneous conversion of $\mathrm{NO}_{2}$ on fresh soot particles and secondary organic aerosols can also form HONO (Ammann et al., 1998; Arens et al., 2001; Ziemba et al., 2010), but the roles of these processes are still under discussion (Arens et al., 2001; Bröske et al., 2003; Aubin et al., 2007; Qin et al.,
2009). Lastly, photolysis of o-nitrophenol and its methylated analogues can produce HONO (Bejan et al., 2006), but this mechanism is only important in urban areas where concentrations of nitrophenols are high.

Comparison of different techniques for detecting HONO is vital to evaluate and enhance their capabilities. This type of intercomparison has been conducted in field campaigns, especially between well accepted long path differential optical absorption spectroscopy (LP-DOAS) and chemical techniques such as denuder (Appel et al., 1990; Febo et al., 1996; Spindler et al., 2003), long path absorption photometry (LOPAP) (Heland et al., 2001; Kleffmann et al., 2006; Acker et al., 2006a), and mist chamber (Stutz et al., 2010). The results in these studies showed consistent agreement in general, although occasionally there were significant differences that could be explained by either an $\mathrm{NO}_{2}$ artifact of the DOAS instruments or possible interferences in the chemical methods (Heland et al., 2001; Kleffmann et al., 2006; Stutz et al., 2010). Excellent agreement has been obtained between LOPAP and LP-DOAS (Acker et al., 2006a; Kleffmann et al., 2006). Chemical Ionization Mass Spectrometry (CIMS) has proven to be a powerful technique to measure many atmospheric trace gases. It has been used to measure HONO in the laboratory (Hirokawa et al., 2009), but rarely in the real atmosphere (Yokelson et al., 2009). Comparison of this new technique with other established techniques for HONO measurement is of particular interest.

Here we present HONO measurement results from the Biosphere Effects on Aerosols and Photochemistry Experiment (BEARPEX) at Blodgett Forest, California in late summer 2007. The mixing ratios and diurnal profile of atmospheric HONO at this site are compared to results obtained from other forested sites. HONO measurements made by wet chemistry and CIMS are compared over three days. Using other concurrent measurements of trace gases and meteorological parameters, a box model was developed and the contribution of $\mathrm{HONO}$ photolysis to $\mathrm{HO}_{\mathrm{x}}$ production was calculated.

\section{Experimental}

\subsection{Site description}

Measurements of $\mathrm{HONO}$ were made within a ponderosa pine plantation adjacent to the University of California at Berkeley's Blodgett Forest Research Station (BFRS). The site is located in the western foothills of the Sierra Nevada mountains $\left(38^{\circ} 58^{\prime} 42.4^{\prime \prime} \mathrm{N}, 120^{\circ} 38^{\prime} 3.4^{\prime \prime} \mathrm{W}, 1315 \mathrm{~m}\right.$ elevation), $\sim 75 \mathrm{~km}$ northeast of Sacramento, CA. Average tree height within the daytime fetch was $7.9 \mathrm{~m}$, and leaf area index (LAI) was estimated as $3.2 \mathrm{~m}^{2} \mathrm{~m}^{-2}$ (Wolfe et al., 2009). Typical meteorological conditions at the site have been described in detail elsewhere (e.g., Goldstein et al., 2000; LaFranchi et al., 2009; Wolfe et al., 2009; Bouvier-Brown et al., 
2009). Briefly, the meteorology during the dry season (MaySeptember) is characterized by high daytime temperatures, low rainfall, low humidity, clear skies, and consistent southwesterly (upslope) wind during the day and northeasterly (downslope) wind at night. During the wet season (OctoberApril), winds are less regular, temperatures are cooler, and there is moderate rainfall and snowfall.

The site contained two sampling towers: an original $15 \mathrm{~m}$ walk-up tower, and a new $18 \mathrm{~m}$ scaffolding tower located $\sim 20 \mathrm{~m}$ north of the old tower. Inlets for HONO instruments were located on the north tower. Other measurements used in our analyses were taken on, or directly adjacent to, the north tower. Power was provided by a propane generator situated $125 \mathrm{~m}$ north of the new tower, perpendicular to our sampling location and the prevailing daytime wind direction. As in previous studies at this site, occasional short-duration plumes from the generator were often detected only during nighttime when winds were weak and variable in direction. HONO measurements with the influence of the generator plumes have been excluded from the analysis.

\subsection{Description of measurement techniques}

\subsubsection{Wet chemistry followed by liquid waveguide long path absorption photometer}

The first technique for measurement of atmospheric HONO is based on aqueous scrubbing followed by nitrite derivatization to a highly light-absorbing azo dye, which is then detected with liquid waveguide long path absorption (Huang et al., 2002; Zhou et al., 2002a). The derivatization to the azo dye is completed through the following nitrite reactions with sulfanilamide (SA) and $\mathrm{N}$-(1-naphthyl) ethylenediamine (NED):

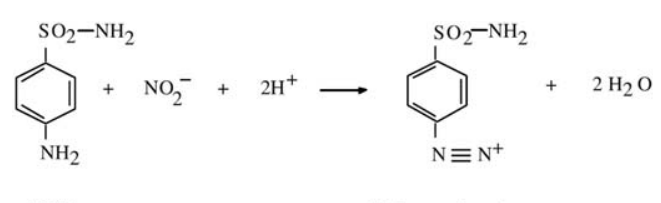

(SA)

(Diazonium)

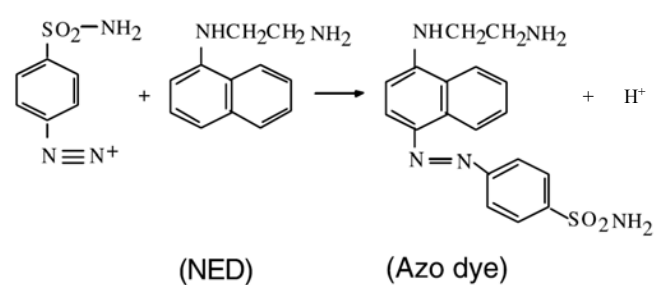

A custom-built wet chemistry HONO instrument was deployed in this study. Ambient air was pulled through a light-shielded Teflon tubing (OD $=0.375^{\prime \prime}$, and $\mathrm{ID}=0.25^{\prime \prime}$, length $=18 \mathrm{~m}$ ) at flow rate of $12 \mathrm{~L} \mathrm{~min}^{-1}$, of which $2 \mathrm{~L} \mathrm{~min}^{-1}$ was fed the HONO instrument housed in a trailer laboratory. The total residence time in the sample line was about $2.8 \mathrm{~s}$. The inlet of the sampling tubing was mounted at a height of $14 \mathrm{~m}$ ( $\sim 6 \mathrm{~m}$ above the canopy). Ambient air was pulled through 10-turn glass coil samplers by a vacuum pump and the air flow rates were controlled by mass flow controllers. A phosphate buffer with a concentration of $1.0 \mathrm{mmol} \mathrm{L}^{-1}$ was used as a scrubbing solution to collect HONO in the air sample. Due to its large effective Henry's Law constant (Park and Lee, 1988), HONO in the air was quantitatively collected in the samplers, confirmed in the collection efficiency experiment (see Sect. 2.3.2). After the separation from the gas phase, the scrubbing solution was mixed with SA/NED reagents. The mixture was then pumped through a Teflon derivatization tubing, where nitrite was converted to the azo dye via the above two Reactions (R1 and R2). The aqueous sample finally flowed through a liquid waveguide capillary cell (LWCC, World Precision Instruments). The absorption of the light from a tungsten light source (FO-6000, World Precision Instruments) by azo dye in the sample was measured using a USB spectrometer (USB4000, Ocean Optics). The scrubbing solution and reagent solutions were delivered using a 16-channel peristaltic pump (Ismatec).

The wet chemistry HONO instrument was calibrated using sodium nitrite $\left(\mathrm{NaNO}_{2}\right)$ standard solutions as well as a HONO generation system as described below. The HONO mixing ratios in air samples can be calculated using the following equation:

$$
[\mathrm{HONO}]_{\mathrm{pptv}}=\frac{C_{l} F_{l} \mathrm{RT}}{F_{g} P} \times 10^{12}
$$

where, $C_{l}$ is nitrite concentration $\left(\mathrm{mol} \mathrm{L}^{-1}\right)$ in the scrubbing solution, $F_{l}$ is the flow rate $\left(\mathrm{cm}^{3} \mathrm{~min}^{-1}\right)$ of the scrubbing solution, $F_{g}$ is the sampling air flow rate $\left(\mathrm{L} \mathrm{min}^{-1}\right), R$ is the gas constant $\left(8.314 \mathrm{~Pa} \mathrm{~m}^{3} \mathrm{~K}^{-1} \mathrm{~mol}^{-1}\right)$, and $T$ and $P$ are the temperature $(294 \mathrm{~K})$ and atmospheric pressure (101325 Pa) under which the mass flow controllers were calibrated. The detection limit of the wet chemistry HONO instrument was about 3 pptv with a 2-min integration time and the measurement uncertainty was about $\pm 15 \%$ at a $2 \sigma$ confidence level.

\subsubsection{Chemical Ionization Mass Spectrometer (CIMS)}

During this study, HONO was also monitored by the Caltech chemical ionization mass spectrometer (Caltech-CIMS) using the $\mathrm{CF}_{3} \mathrm{O}^{-}$reagent ion, via the fluoride transfer product ion channel $\left(m / z=66, \mathrm{HFNO}_{2}^{-}\right)$.

$\mathrm{CF}_{3} \mathrm{O}^{-}+\mathrm{HONO} \rightarrow \mathrm{HFNO}_{2}^{-}+\mathrm{CF}_{2} \mathrm{O}$

The instrument was situated on top of the north tower during this study with an inlet height of $\sim 17.7 \mathrm{~m}$ above ground level. Ambient air was sampled through the same glass inlet described in Crounse et al. (2006) with the exception that parts A, B, D, and E (Fig. 1, Crounse et al., 2006) were not part of the BEARPEX CIMS instrument configuration. Air was drawn through the large inlet tube $(C)$ at a linear flow rate of $\sim 10 \mathrm{~m} / \mathrm{s}$ using a wet/dry vacuum. Air was sub-sampled 


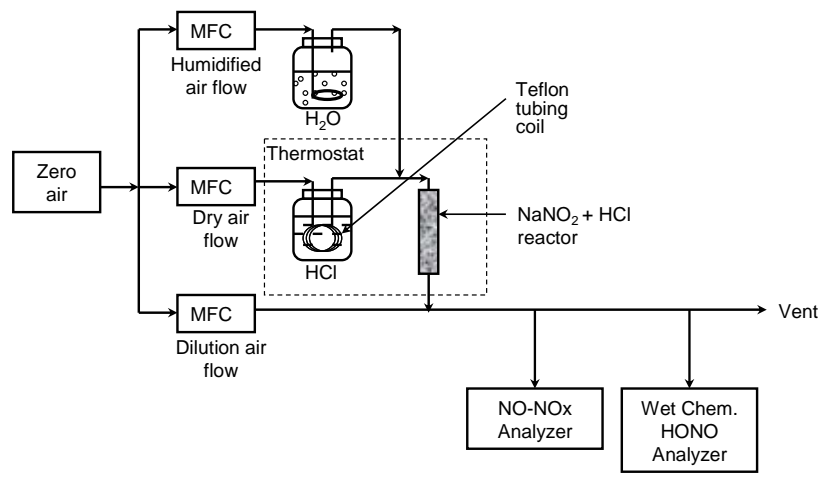

Fig. 1. Schematic of a HONO generation system. MFC represents a mass flow controller.

for analysis from the center of the large flow as described in Crounse et al. (2006) with the difference that ambient air was diluted with UHP $\mathrm{N}_{2}$ in a 1:3.5 ratio to reduce the water vapor mixing ratio in the flow tube $(J)$. Also the glass inlet tube was encased in a stainless steel tube and shielded from light.

Due to the time needed to measure other chemical species, the ion channel $\mathrm{m} / z=66$ was only monitored $2.8 \%$ of the time (i.e., $0.5 \mathrm{~s}$ every $18 \mathrm{~s}$ ). Instrument zeros were conducted approximately once every $15 \mathrm{~min}$ by passing ambient air through a filter filled with nylon wool that was coated with sodium bicarbonate. In-situ calibrations were conducted approximately once every $1.5 \mathrm{~h}$ using $\mathrm{H}_{2} \mathrm{O}_{2}$ and $\mathrm{HNO}_{3}$ standards, and proxied to HONO using laboratory calibrations curves. The primary interference to the HONO signal, formic acid product ion $\left({ }^{13} \mathrm{CH}(\mathrm{O}) \mathrm{O}^{-} \mathrm{HF}\right)$, has been removed using the signal at $m / z=65\left({ }^{12} \mathrm{CH}(\mathrm{O}) \mathrm{O}^{-} \mathrm{HF}\right)$. Additional detailed information about this instrument can be found elsewhere (Crounse et al., 2006). The precision for a 0.5-s integration period was about $25 \operatorname{pptv}(1 \sigma)$.

The Caltech-CIMS was operational between 15 August and 27 September, 2007 with the exception of several periods of downtime due to rain and technical difficulties. The wet chemistry HONO measurements covered the period between 25 September and 10 October, 2007. Both wet chemistry and CIMS measured HONO on three overlapping days, 25-27 September, allowing for the HONO intercomparison between wet chemistry and CIMS.

\subsubsection{Other measurements}

Other concurrent measurements used in this analysis include ozone based on UV absorption, $\mathrm{NO}_{2}$, alkyl nitrates (ANs) and peroxy nitrates (PNs) based on thermo-dissociation laser induced fluorescence (TD-LIF) (Thornton et al., 2000), OH and $\mathrm{HO}_{2}$ based on laser-induced fluorescence (Faloona et al., 2004), and meteorological parameters, including ambient temperature, pressure, relative humidity, wind direction, wind speed, and solar radiation. There were no direct mea- surements of photolysis frequencies (J values). The NCAR Tropospheric Ultraviolet and Visible (TUV) transfer model (http://www.acd.ucar.edu/TUV) was used to calculate clear sky $\mathbf{J}$ values with the $\mathrm{O}_{3}$ column density measured by the Total Ozone Mapping Spectrometer (TOMS, data available at http://toms.gsfc.nasa.gov/teacher/ozone_overhead.html). In order to correct for solar attenuation by clouds, the calculated $\mathbf{J}$ values on a clear day were used to calculate a cloudiness factor. The field experiment $\log$ and the profile of the solar radiation measured on 1 September 2007 indicated that it was a clean day with a clear sky. Thus the ratio of clearsky photolysis frequency to solar radiation intensity for each photolytic species on this day was calculated and used as a reference to correct the cloud attenuation. The $\mathrm{J}$ values on other days were then scaled to the measured solar radiation intensity.

During this study, the measurement of NO failed due to technical difficulties. Previous studies at this site have found that $\mathrm{NO}, \mathrm{NO}_{2}$, and $\mathrm{O}_{3}$ approximately reached photostationary state (PSS) during midday (e.g., Day et al., 2009). With the PSS approximation and the concurrent measurements of $\mathrm{NO}_{2}, \mathrm{O}_{3}$ and $\mathrm{HO}_{2}$, daytime $\mathrm{NO}$ concentrations were calculated using Eq. (2):

$[\mathrm{NO}]_{\mathrm{SS}}$

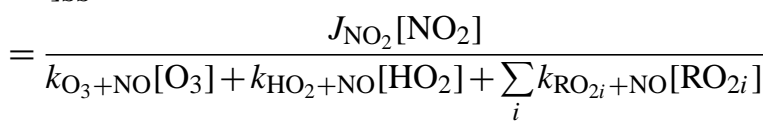

Peroxy radicals were not measured and we assume that total $\mathrm{RO}_{2}$ levels were 1.6 times $\mathrm{HO}_{2}$ levels, a median daytime $\mathrm{RO}_{2} / \mathrm{HO}_{2}$ ratio in the box model. We also assume that the rate coefficients for the $\mathrm{RO}_{2}+\mathrm{NO}$ reactions are the same as the rate coefficient for the $\mathrm{CH}_{3} \mathrm{O}_{2}+\mathrm{NO}$ reaction. Nighttime $\mathrm{NO}$ concentrations are assumed to be the same as the mean nighttime concentrations measured during BEARPEX2009 in summer 2009. As NO only contributed a small fraction $(2-10 \%)$ to $\mathrm{NO}_{\mathrm{y}}$ at this site (Fig. 8), the uncertainty in the calculated $\mathrm{NO}$ does not significantly affect the $\mathrm{NO}_{\mathrm{y}}$ speciation (Sect. 3.4).

\subsection{Laboratory characterization of the wet chemistry HONO instrument}

\subsubsection{HONO generation system}

A HONO generation system was developed to quantitatively produce HONO with high purity and high stability. It is based on the reaction between gaseous hydrogen chloride $(\mathrm{HCl})$ and solid sodium nitrite $\left(\mathrm{NaNO}_{2}\right)$ (Febo et al., 1995):

$\mathrm{NaNO}_{2(\mathrm{~s})}+\mathrm{HCl}_{(\mathrm{g})} \rightarrow \mathrm{HONO}_{(\mathrm{g})}+\mathrm{NaCl}_{(\mathrm{s})}$

The gaseous $\mathrm{HCl}$ was produced using a piece of thin-wall Teflon tubing that was immersed into a concentrated hydrochloric acid solution (9-12 $\mathrm{mol} \mathrm{L}^{-1}$, Fig. 1). A small zero air flow was introduced into the Teflon tubing as a carrier gas. 
Because of the partial pressure difference in $\mathrm{HCl}_{(\mathrm{g})}$ between the inside and outside of the Teflon tubing, small amount of gas phase $\mathrm{HCl}$ diffused into the carrier gas. The produced $\mathrm{HCl} /$ air mixture was mixed with some humidified air produced with a water bubbler before entering a small reactor containing $\mathrm{NaNO}_{2}$ powder (the $\mathrm{NaNO}_{2}-\mathrm{HCl}$ reactor), where the $\mathrm{NaNO}_{2}+\mathrm{HCl}$ reaction occurred. The produced $\mathrm{HONO}$ flow was diluted by zero air before it was measured by an NO-NO ${ }_{x}$ analyzer (TEI, Model 42i-TL, Thermo Fisher) and/or the wet chemistry HONO instrument. The NO-NO analyzer contains a molybdenum catalytic converter to quantitatively convert HONO into NO followed by the chemiluminescence detection of NO. These chemiluminescence detectors with molybdenum converters have been proven to have near unit response to HONO (Allegrini et al., 1990; Pérez et al., 2007). In order to stabilize the HONO levels from the calibration source, the temperature of the hydrochloric acid solution and the $\mathrm{NaNO}_{2}-\mathrm{HCl}$ reactor, as well as the humidity in the air through the $\mathrm{NaNO}_{2}-\mathrm{HCl}$ reactor were controlled. The produced HONO levels can be varied over three orders, from a few tens of pptv to a few tens of ppbv by varying the length of the Teflon tubing immersed into the hydrochloric acid, the concentration and temperature of hydrochloric acid, and the dilution flow rate of zero air.

The HONO generation system was tested in the laboratory and the produced HONO was sampled simultaneously by the wet chemistry HONO instrument and the NO-NO analyzer. The HONO instrument was calibrated using standard solutions of $\mathrm{NaNO}_{2}$ and the $\mathrm{NO}-\mathrm{NO}_{\mathrm{x}}$ analyzer was calibrated with a cylindered NO calibration mixture $(9.96 \mathrm{ppmv}$ of $\mathrm{NO}$ in $\mathrm{N}_{2}$ with a $\pm 2 \%$ uncertainty, Matheson Tri-Gas). Very good agreement was obtained between the two measurements (Fig. 2), suggesting the reliability of the HONO instrument and HONO generation system.

\subsubsection{Collection efficiency and delay time}

In addition to the calibration of the wet chemistry HONO instrument, the HONO generation system was used to characterize the collection efficiency and delay time (the time when an air sample reaches the samplers to the time when the sample signal appears in the detection cell) of the HONO instrument. The coil samplers used in this study have an uptake efficiency of $(99.6 \pm 0.5) \%$ for $\mathrm{HONO}$ at a sampling flow rate of $2 \mathrm{~L} \mathrm{~min}^{-1}$. The instrument delay time was $12.9 \pm 0.8 \mathrm{~min}$, which includes the derivatization time $(5 \mathrm{~min})$ and the time for the reagent solutions to flow through autoanalysis tubings attached onto the peristaltic pump. The gas-phase HONO source was also used to examine the loss of HONO in the sampling tubing. Pre-campaign and post-campaign tests show that the wall loss was little and $(99.2 \pm 1.3) \%$ of HONO went through the tubing.

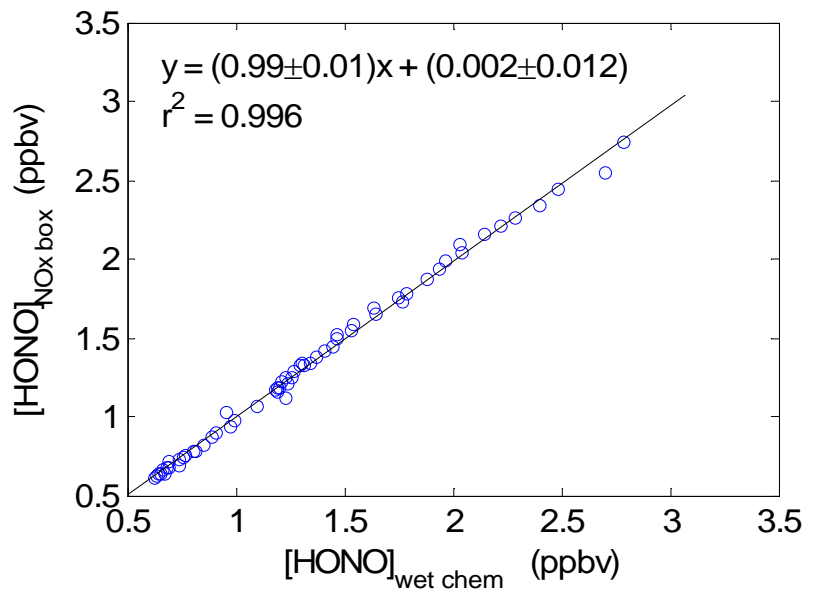

Fig. 2. Comparison of HONO measurements with a wet chemistryHONO instrument and a TEI NO-NO $\mathrm{N}_{\mathrm{x}}$ analyzer. HONO source was produced by a HONO generation system.

\subsubsection{Interference tests}

HONO measurements based on chemical methods can suffer from a variety of interferences (Kleffmann and Wiesen, 2008; Stutz et al., 2010). Therefore HONO instruments based on wet chemistry need to be carefully designed and characterized. Heland et al. (2001) and Huang et al. (2002) have tested several possible interferences for their instruments and all tested species showed insignificant interferences to $\mathrm{HONO}$ measurement. In the laboratory, we also tested several candidate chemicals, including $\mathrm{NO}_{2}, \mathrm{HNO}_{3}$, nitrate, and $\mathrm{SO}_{2}$, for possible interferences in our HONO instrument.

$\mathrm{NO}_{2}$ is slightly soluble in liquid water with a Henry's Law constant of $0.01 \mathrm{~mol} \mathrm{~L}^{-1} \mathrm{~atm}^{-1}$ (Schwartz and White, 1981). Assuming that the air sample contains $100 \mathrm{ppbv}$ of $\mathrm{NO}_{2}$ at $1 \mathrm{~atm}$ pressure and $\mathrm{NO}_{2}$ reaches equilibrium when air passes through the glass coil sampler, the concentration of the formed nitrous acid in the aqueous phase is about $1.0 \mathrm{nmol} \mathrm{L}^{-1}$, which corresponds to $3.4 \mathrm{pptv}$ of HONO under typical sample conditions. Zero air containing approximately $100 \mathrm{ppbv}$ of $\mathrm{NO}_{2}$ was used to test the actual $\mathrm{NO}_{2}$ interference to the $\mathrm{HONO}$ measurement. The $\mathrm{NO}_{2}$-air mixture was generated by an $\mathrm{NO}_{2}$ permeation tube (VICI Metronics) using a Dynacalibrator (VICI Metronics). There was an observed small fraction of $\mathrm{HONO}$ (about $1 \%$ of $\mathrm{NO}_{2}$ level) in the $\mathrm{NO}_{2}$ source, either existing in the $\mathrm{NO}_{2}$ permeation tube or formed on the surfaces inside the Dynacalibrator. In order to test the true interference from $\mathrm{NO}_{2}$, the $\mathrm{NO}_{2}$ mixture was passed through a dry glass annular denuder (URG) coated with sodium carbonate. The denuder removed all HONO but only removes about $5 \%$ of $\mathrm{NO}_{2}$. The interference was found to be about $20 \mathrm{pptv}$ of $\mathrm{HONO}$ per $100 \mathrm{ppbv}$ of $\mathrm{NO}_{2}$, or $0.02 \%$ of $\mathrm{NO}_{2}$, which is small considering the relatively low $\mathrm{NO}_{2}$ levels at Blodgett Forest (i.e., up to $\sim 3$ ppbv of $\mathrm{NO}_{2}$, 
which corresponds to an interference level of $\sim 0.6 \mathrm{pptv}$ of HONO). This interference level is comparable to what was found by Heland et al. (2001) with an interference level of $(0.011 \pm 0.005) \%$, but greater than the estimation based on the Henry's Law constant of $\mathrm{NO}_{2}$, possibly due to the $\mathrm{NO}_{2}$ reaction with $\mathrm{H}_{2} \mathrm{O}$, leading to a larger effective $\mathrm{NO}_{2}$ solubility than the equilibrium based on the Henry's Law.

Possible interferences from $\mathrm{HNO}_{3}$ and nitrate were tested using an $\mathrm{HNO}_{3}$ permeation tube (VICI Metronics) to generate an air flow with an $\mathrm{HNO}_{3}$ mixing ratio of $\sim 5 \mathrm{ppbv}$ or using sodium nitrate standard solutions $\left(80-400 \mathrm{nmol} \mathrm{L}^{-1}\right)$. There was no detectable interference (below the detection limit) from either test. Interference from pure $\mathrm{SO}_{2}$ was tested with an $\mathrm{SO}_{2}$ /air mixture containing an $\mathrm{SO}_{2}$ mixing ratio of $\sim 50 \mathrm{ppbv}$, which was sampled by the HONO instrument. Interference from the $\mathrm{SO}_{2}+\mathrm{NO}_{2} /$ Air mixture was also tested. The interference in both tests was found to be small and negligible.

In the field, another interference test was conducted using a dry annular denuder coated with sodium carbonate by connecting the denuder to the sampling inlet. The test was designed to characterize interferences from aerosols and other nitrogen species (e.g., $\mathrm{NO}_{\mathrm{x}}, \mathrm{PAN}$, and other organic nitrates) in air samples by removing HONO but retaining most of particles, $\mathrm{NO}_{2}$, PAN or other organic nitrates in the air flow. The signals obtained from the ambient air through the denuder were essentially the same as the signals from zero air, indicating that there were no significant $\mathrm{HONO}$ interferences from the possible interfering species such as $\mathrm{NO}_{2}$, aerosols, and organic nitrates in this environment.

\section{Results and discussion}

\subsection{Measurements of meteorological parameters and trace gases}

Shown in Fig. 3 are meteorological measurements from the last two weeks of the BEARPEX2007 study, when the wet chemistry HONO measurements were available. Summer 2007 was cooler than usual. There were slight rainfalls on nights of 28/29 September and 9/10 October. An early snowfall came on 5 October 2007. During this period, wind directions were less regular due to a few cold fronts crossing over the site (Fig. 3).

HONO measurements made by wet chemistry during the last two weeks of BEARPEX2007 exhibit a large variability ranging from near 0 to $160 \mathrm{pptv}$ (Fig. 4). Meteorological conditions affected the HONO mixing ratio significantly at this forested site. For example, a rapid drop in HONO mixing ratios from near $100 \mathrm{pptv}$ to $\sim 25 \mathrm{pptv}$ at $\sim 21: 30$ (PST) on 28 September (Fig. 4) was primarily caused by a rapid wind shift from southwesterly to northerly followed by a slight rainfall. Another example of meteorological influence on HONO took place on the night of $9 / 10$ October when

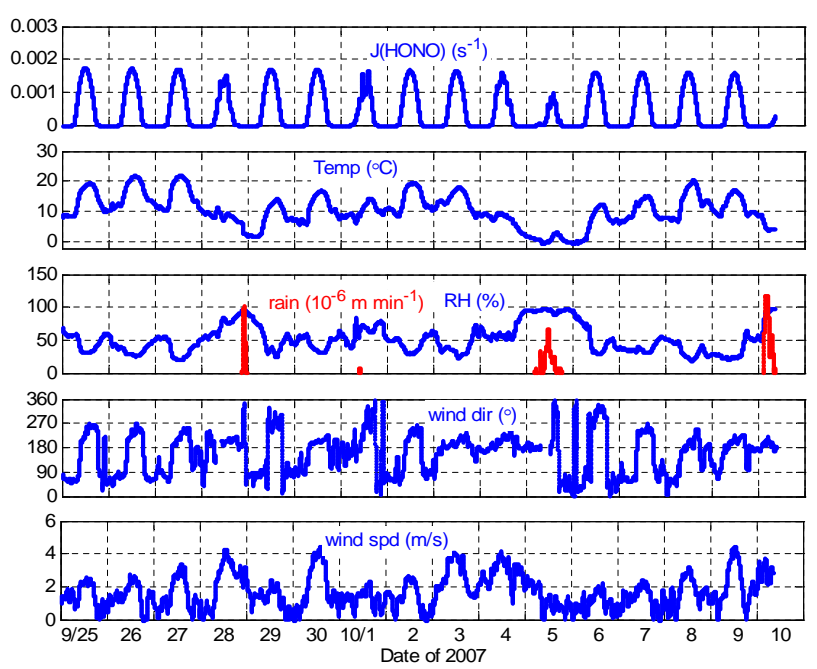

Fig. 3. Time series of HONO photolysis frequency, temperature, relative humidity, rain fall, wind direction, and wind speed between 25 September and 10 October 2007 during BEARPEX2007 when the wet chemistry HONO measurements were available. $J(\mathrm{HONO})$ was calculated based on the TUV model and measured solar radiation (see Sect. 2.2.3 for details).

the wind started to shift from southwesterly to easterly at $\sim$ 17:00 (PST). In about two hours, the wind shifted back to southerly and remained in this direction for the remainder of the night. Because the southerly wind continued to blow the urban plumes to the site as a cold front passed by, HONO mixing ratios continuously increased to a maximum level of 160 pptv. A slight rainfall started at around 03:00 (PST) on 10 October when HONO mixing ratio started to drop dramatically (Fig. 4).

During this study, $\mathrm{HONO}$ and $\mathrm{NO}_{2}$ generally correlated well as expected (Figs. 4 and 5), indicating that $\mathrm{NO}_{2}$ might be a key HONO precursor in this environment. Simultaneously there were a few periods when $\mathrm{HONO}$ and $\mathrm{NO}_{2}$ did not correlate well. For instance, on both 3 and 4 October, measured $\mathrm{NO}_{2}$ mixing ratios were up to $3 \mathrm{ppbv}$ in the late afternoon and early evening because the wind continuously blew from south and southwest without a regular wind shift (Fig. 3). However, when $\mathrm{NO}_{2}$ reached its peak values, HONO mixing ratios on both days remained at relatively low levels (near or below $50 \mathrm{pptv}$ ), possibly because of not enough interaction time between $\mathrm{NO}_{2}$ and surfaces before the air masses reached the site. The observed HONO-to- $\mathrm{NO}_{2}$ ratios show a large variability ranging from near 0 to 0.5 (Fig. 4). For a $24-\mathrm{h}$ period, the $\mathrm{HONO} / \mathrm{NO}_{2}$ ratios ranged from 0.05 to 0.13 , with a mean ratio of 0.07 (Fig. 5), which is comparable to the ratios at some forested sites in Europe (e.g., Acker et al., 2006b, 2007), but lower than the ratios observed at another forested site at Whiteface Mt., New York (Ren et al., 2006; Zhou et al., 2007), where the average $\mathrm{HONO} / \mathrm{NO}_{2}$ ratios ranged from 0.15 to 0.40 . 

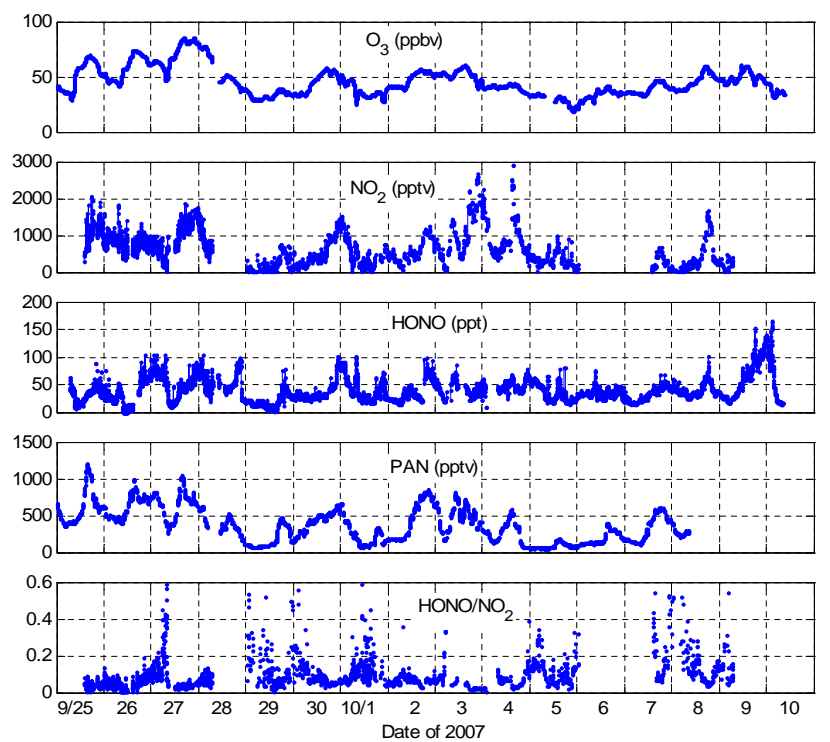

Fig. 4. Time series of measured ozone, $\mathrm{NO}_{2}, \mathrm{PAN}, \mathrm{HONO}$, and $\mathrm{HONO} / \mathrm{NO}_{2}$ ratio between 25 September and 10 October during BEARPEX2007. HONO measurements made by wet chemistry are shown. PAN was measured using CIMS (Wolfe et al., 2009).

\subsection{Intercomparison of wet chemistry and CIMS}

Time series of HONO measurements collected between 25 and 27 September, 2007 by wet chemistry and CIMS show very good agreement (Fig. 5), although the CIMS HONO measurements are a little noisy especially at low HONO levels, primarily due to the large uncertainty of the CIMS measurements and a small fraction $(\sim 3 \%)$ of the CIMS measurement time dedicated to HONO measurement for the need of measuring other species. Using 10-min averages, the linear regression of the CIMS HONO versus the wet chemistry HONO produces a slope of 0.94 and an intercept of 4.6 pptv with $r^{2}$ of 0.64 (Fig. 5). The fact that wet chemistry and CIMS are different techniques for HONO measurements indicates reliable HONO measurements by both instruments, unless both instruments have the same biases in the HONO measurements. In a recent HONO intercomparison (HINT2009) study in Houston, TX where we deployed our wet chemistry HONO instrument, very good agreement was also obtained between our wet chemistry and four different techniques, including LP-DOAS (within $\pm 20 \%, r^{2}=0.79$ ) and tunable infrared laser differential absorption spectrometry (within $\pm 15 \%, r^{2}=0.86$ ) (Thomas et al., 2010).

\subsection{Diurnal trends of measured HONO}

The diurnal profile during this study shows that the minimum HONO mixing ratios were about $\sim 20-30$ pptv in the midday and maximum levels of 60-70 pptv at night (Fig. 6). These daytime HONO levels are lower than levels observed in some
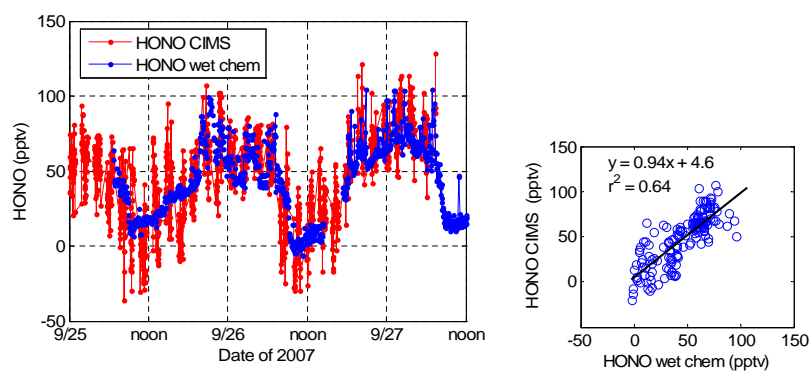

Fig. 5. Comparison of HONO measurements by wet chemistry (blue dots) and CIMS (red circles) over three days between 25 and 27 September, 2007. Left: time series with one-minute averages. Right: scatter plot of CIMS HONO versus wet chemistry HONO with 10 -min averages.

other forested sites. For example, at two forested sites in Eastern US (in Whiteface Mountain, New York, Ren et al., 2006) and Europe (in Hohenpeissenberg, Germany, Acker et al., 2006b), daytime HONO levels of 80 to $120 \mathrm{pptv}$ while minima of 20-60 pptv at night were observed. Thus the diurnal pattern of HONO observed at Blodgett Forest is quite different from what was observed in the other two studies. The reasons for these differences are uncertain, but they may be related to the dry climatology and unique diurnal wind pattern (i.e., southwesterly wind during the day and northeasterly wind at night) at Blodgett Forest. Another possible explanation may be related to the acid precipitation in Eastern US and Europe, where soil acidification has occurred (Menz and Seip, 2004). Soil acidification is less prominent in Western US than in Northeast US and Europe (Fenn et al., 2006), so the heterogeneously formed HONO on the ground surface at Blodgett Forest may be less likely to be released into the atmosphere than at other forest sites where soil acidification is significant. One piece of evidence supporting this hypothesis is the aerosol measurements by an aerosol mass spectrometer (AMS), which confirm that aerosols at Blodgett Forest were close to fully neutralized (D. Farmer, unpublished data).

Under less acidic conditions, nitrate photolysis may not be a significant HONO source, and heterogeneous hydrolysis of $\mathrm{NO}_{\mathrm{x}}$ may act as a major HONO source. This can explain the different HONO behaviors at Blodgett Forest and at the sites in Eastern US and Europe, i.e., the lower daytime HONO at Blodgett Forest while daytime HONO maxima in Eastern US and Europe (Ren et al., 2006; Acker et al., 2006, 2007) and good correlation between $\mathrm{HONO}$ and $\mathrm{NO}_{2}$ at Blodgett Forest while low correlation $\left(r^{2} \sim 0.01-0.05\right)$ in Pinnacle and Whiteface Mountain, New York (Zhou et al., 2002a, 2007).

More evidence supporting this hypothesis came from recent studies in the Artic and Antarctic. In the Arctic significant HONO emissions have been observed from the sunlightexposed snowpack via the photolysis of $\mathrm{HNO}_{3}$ /nitrate (possibly involving electron transfer reactions of $\mathrm{NO}_{2}$ from 

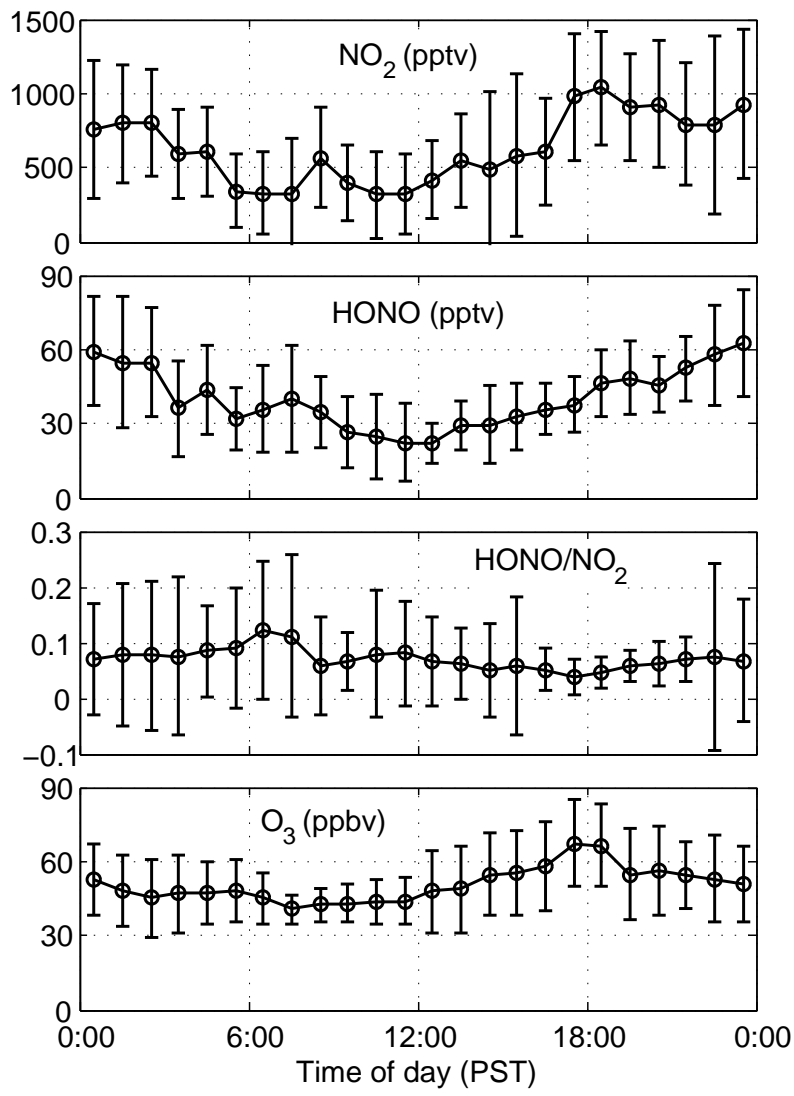

Fig. 6. Average diurnal profiles of $\mathrm{O}_{3}, \mathrm{NO}_{2}, \mathrm{HONO}$, and $\mathrm{HONO} / \mathrm{NO}_{2}$. HONO was measured at a height of $14 \mathrm{~m}(\sim 6 \mathrm{~m}$ above the canopy) by the wet chemistry $\mathrm{HONO}$ instrument and $\mathrm{NO}_{2}$ was measured at a height of $12.7 \mathrm{~m}$. The data were collected between 25 September and 10 October during BEARPEX2007. Error bars represent standard deviations in hourly bins.

photosensitized organics, Beine et al., 2006) that come primarily from the deposition of acidic aerosols transported from North America, Asia and Europe (Zhou et al., 2001; Honrath et al., 2002). In contrast, little HONO was produced from coastal snowpack in the Antarctic where significant seasalt deposition occurred and $\mathrm{NO}_{3}^{-}$ion was present primarily as $\mathrm{NaNO}_{3}$ in aged snows, thus preventing the release of or providing a reactive medium for newly formed HONO (Beine et al., 2006). Recent laboratory studies (H. Gao, unpublished data) also found that HONO production from surface $\mathrm{HNO}_{3} /$ nitrate photolysis diminished with higher $\mathrm{pH}$. The rate of HONO production decreased to half for surface $\mathrm{NH}_{4} \mathrm{NO}_{3}$ photolysis compared to $\mathrm{HNO}_{3}$ photolysis, but little HONO was produced from surface $\mathrm{NaNO}_{3}$ photolysis, consistent with the results by Beine et al. (2006). While it seems likely to us that the different behaviors of HONO observed at Blodgett Forest are associated with the low soil acidification and acid precipitation in Western US, further studies of HONO in this kind of environment are needed to test this hypothesis.

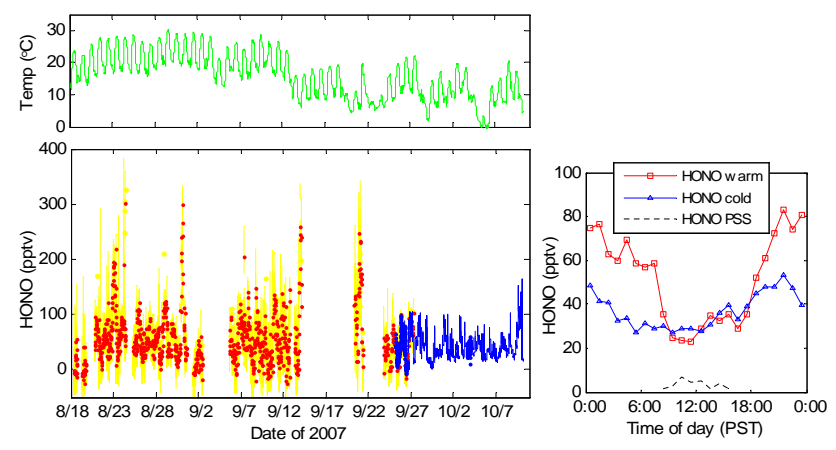

Fig. 7. Left: time series of measured HONO mixing ratios by CIMS ( 1 min averages in yellow and 10 min averages in red) and by wet chemistry (in blue) and temperature (in green). The integration time is 2 min for the wet chemistry HONO instrument. The integration time is $0.5 \mathrm{~s}$ every $18 \mathrm{~s}$ and 1 -min averages are shown in this figure. Right: diurnal variations of HONO mixing ratio during the warm period (red squares) and cool period (blue triangles). Also plotted are the photo-steady state (PSS) HONO mixing ratios (dashed black line) averaged for the entire study. In the PSS calculation, only gas phase HONO sources are included during the day between 08:00 and 16:00 (PST).

Temperature dependence of HONO mixing ratios was observed during BEARPEX2007. Figure 7 shows both HONO measurements made by CIMS and wet chemistry together with ambient temperature. There were two distinguishing periods: a warm period between 18 August and 12 September, and a cool period from 13 September to 10 October. There was a three-day overlap between CIMS and wet chemistry measurements, which will be discussed in detail in Sect. 3.3. Interestingly, the temperature dependence occurred mainly at night, with higher nighttime HONO mixing ratios during the warm period (Fig. 7). During the day, the two periods had very similar observed HONO levels at $\sim 20-40$ pptv. It is noted that diurnal variations of $\mathrm{NO}_{2}$ mixing ratios during these two periods are about the same, but the water mixing ratios in the air during the warm period was higher than in the cold period by a factor of 1.2 , which may be partially responsible for the difference in the nighttime HONO mixing ratios during these two periods.

During the daytime (08:00-16:00 PST), the photolytic loss of HONO is very efficient due to its large photolysis rate coefficients ranging from 0.001 to $0.002 \mathrm{~s}^{-1}$. It is reasonable to assume that HONO reaches photo-steady state (PSS) in the midday. If we assume that only gas phase HONO sources (mainly the $\mathrm{OH}+\mathrm{NO}$ reaction) are involved in the HONO production, we can then calculate PSS HONO mixing ratios, shown in Fig. 7. The PSS HONO mixing ratios calculated with gas phase HONO sources only are lower than the measurements by a factor of 9 on average, indicating that other HONO sources are dominant in this environment. This result is consistent with previous studies (e.g., Zhou et al., 2002; Acker et al., 2006b, 2007). Calculations also show that a 

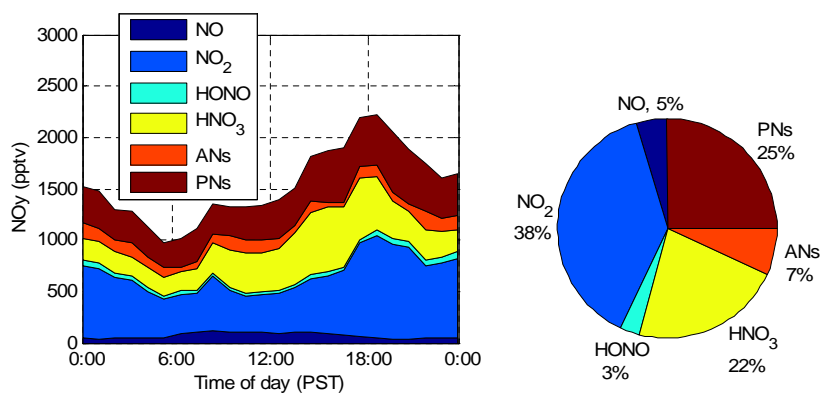

Fig. 8. Median diurnal variations (left) and distribution (right) of $\mathrm{NO}_{\mathrm{y}}$ species during BEARPEX2007. ANs represents total alkyl nitrates and PNs represents total peroxy nitrates. The pie chart is representative of a $24-\mathrm{h}$ basis. Data collected between 15 August and 10 October, 2007 are used in this figure.

significant HONO source $\left(\sim 1.59 \mathrm{ppbv} \mathrm{day}^{-1}\right)$ is needed in order to sustain the observed HONO level, which presumably comes from heterogeneous processes.

\section{4 $\mathrm{NO}_{\mathrm{y}}$ speciation}

The sum of reactive nitrogen species in the atmosphere is called $\mathrm{NO}_{\mathrm{y}}$, which is defined here as the sum of $\mathrm{NO}+\mathrm{NO}_{2}+\mathrm{HONO}+\mathrm{HNO}_{3}+$ alkyl nitrates (ANs) + peroxy nitrates $(\mathrm{PNs})+\mathrm{HO}_{2} \mathrm{NO}_{2}+\mathrm{NO}_{3}+2 \cdot \mathrm{N}_{2} \mathrm{O}_{5}$. Box model results show that $\mathrm{N}_{2} \mathrm{O}_{5}$ and $\mathrm{NO}_{3}$ were lower than 1 pptv while $\mathrm{HO}_{2} \mathrm{NO}_{2}$ was typically less than $10 \mathrm{pptv}$ during BEARPEX2007 and thus they do not contribute significantly to the $\mathrm{NO}_{\mathrm{y}}$ budget. In the following discussion, we assume that $\mathrm{NO}_{\mathrm{y}}$ comprises $\mathrm{NO}, \mathrm{NO}_{2}, \mathrm{HONO}, \mathrm{HNO}_{3}, \mathrm{ANs}$, and PNs.

Diurnal profiles of reactive nitrogen species exhibit a minimum at 06:00 (PST) and a maximum $\mathrm{NO}_{\mathrm{y}}$ at 18:00 (PST) (Fig. 8), due to the primary influence of the Sacramento urban plume and the unique diurnal wind pattern at Blodgett Forest. Similar diurnal variations have been observed in previous studies at this site (e.g., Murphy et al., 2006; Farmer et al., 2008; Day et al., 2009). Among the reactive nitrogen species, $\mathrm{NO}_{2}, \mathrm{HNO}_{3}$, and PNs are dominant and account for $85 \%$ of total $\mathrm{NO}_{\mathrm{y}}$ on a $24-\mathrm{h}$ basis (Fig. 8). HONO accounted for only $2.8 \%$ of total $\mathrm{NO}_{\mathrm{y}}$ on average, with a percentage of $2.2 \%$ during the day and $3.3 \%$ at night. However, due to fast HONO loss through photolysis, a strong HONO production rate $\left(1.59 \mathrm{ppbv} \mathrm{day}^{-1}\right)$ existed in this environment, suggesting that $\mathrm{HONO}$ plays an important role in $\mathrm{NO}_{\mathrm{y}}$ cycling. In contrast, $\mathrm{HNO}_{3}$ production rate from the $\mathrm{OH}+\mathrm{NO}_{2}$ reaction was $0.53 \mathrm{ppbv} \mathrm{day}^{-1}$ on average, which is only one third of the HONO production rate.

The production of NO from the photolysis of HONO may potentially affect the cycling between $\mathrm{NO}_{2}$ and NO. Calculations show that the HONO photolysis rate was only about $1.5 \%$ of the $\mathrm{NO}_{2}$ photolysis rate, indicating that HONO photolysis did not significantly influence the NO- $\mathrm{NO}_{2}$ cycling,

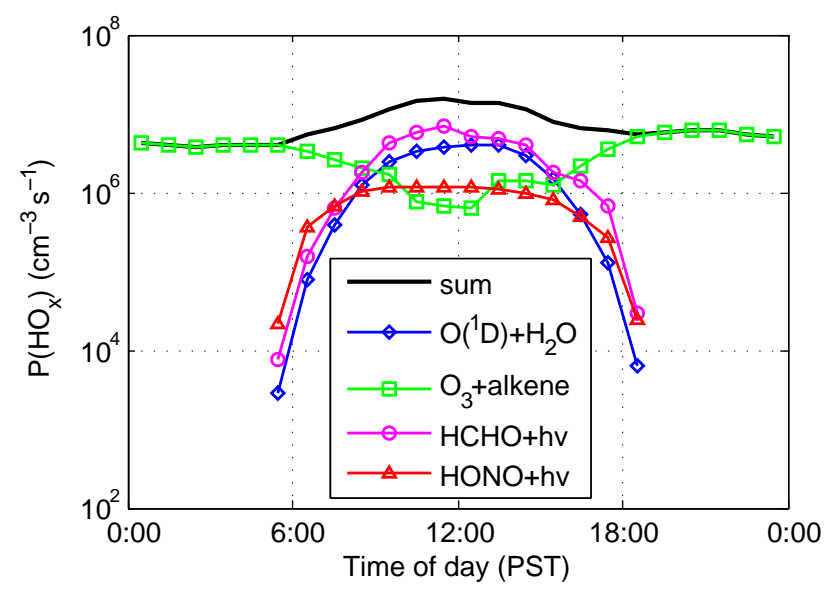

Fig. 9. Diurnal variation of $\mathrm{HO}_{\mathrm{x}}$ production rates from the photolysis of ozone followed by the consequent $\mathrm{O}\left({ }^{1} \mathrm{D}\right)+\mathrm{H}_{2} \mathrm{O}$ reaction (diamonds), the photolysis of HCHO (circles), the photolysis of HONO (triangles), and from the reactions of $\mathrm{O}_{3}+$ alkenes (squares).

mainly due to the low HONO levels during the day and fast cycling between $\mathrm{NO}_{2}$ and $\mathrm{NO}$.

\subsection{Contribution of HONO photolysis to $\mathrm{HO}_{\mathrm{x}}$ production}

A box model based on the Regional Atmospheric Chemistry Mechanism (RACM) (Stockwell et al., 1997) was developed to interpret the field measurements and investigate atmospheric oxidation chemistry in this environment. The model was constrained by the available simultaneous measurements in this study and calculated concentrations of free radicals, such as $\mathrm{OH}, \mathrm{HO}_{2}$, and $\mathrm{RO}_{2}$. Similar model simulations have been conducted in previous studies (e.g., Ren et al., 2003, 2006). Using the model results, the contribution of $\mathrm{HONO}$ photolysis to $\mathrm{HO}_{\mathrm{x}}$ production can be calculated.

The diurnal profile of $\mathrm{HO}_{\mathrm{x}}$ production shows that $\mathrm{HO}_{\mathrm{x}}$ production was primarily from the photolysis of $\mathrm{HCHO}$ and $\mathrm{O}_{3}$ during the day, while nighttime $\mathrm{HO}_{\mathrm{x}}$ was mainly produced from $\mathrm{O}_{3}+$ alkene reactions (Fig. 9). The photolysis of $\mathrm{HONO}$ did not contribute significantly to $\mathrm{HO}_{\mathrm{x}}$ production even in the early morning due to its relatively low mixing ratios. On a 24-h basis, HONO photolysis only accounted for about $6 \%$ of total $\mathrm{HO}_{\mathrm{x}}$ production.

The insignificant contribution of $\mathrm{HONO}$ photolysis to $\mathrm{HO}_{\mathrm{x}}$ production at Blodgett Forest is in contrast with the results from some studies at other forested sites. For instance, at a forested site in Whiteface Mountain, Northern New York State, HONO photolysis was found to be a dominant $\mathrm{HO}_{\mathrm{x}}$ source in the early morning and late afternoon with an overall contribution of $34 \%$ to $\mathrm{HO}_{\mathrm{x}}$ production on a $24-\mathrm{h}$ basis (Ren et al., 2006). At another rural site in New York State, the average radical production from HONO photolysis was 2.3 ppbv day ${ }^{-1}$ and accounted for $24 \%$ of the total $\mathrm{HO}_{\mathrm{x}}$ 
production (Zhou et al., 2002a). In a study at the Meteorological Observatory Hohenpeissenberg in Germany, HONO photolysis was also found to be a dominant $\mathrm{HO}_{\mathrm{x}}$ source in the early morning and the overall contribution of HONO photolysis comprised $42 \%$ of total photolytic $\mathrm{HO}_{\mathrm{x}}$ production (Acker et al., 2006a). Kleffmann et al. (2005) found that HONO photolysis contributed about $33 \%$ of total $\mathrm{OH}$ production in a forest in Jülich, Germany.

The reasons for the smaller HONO mixing ratios and thus smaller contribution of $\mathrm{HONO}$ photolysis to $\mathrm{HO}_{\mathrm{x}}$ production at Blodgett Forest are uncertain. As discussed previously, it may be related to the dry climatology and low acid precipitation in this water-limited environment.

\section{Conclusions}

The measurement suite of $\mathrm{HONO}$ and other $\mathrm{NO}_{\mathrm{y}}$ species during BEARPEX2007 at Blodgett Forest in summer/fall 2007 provides a great opportunity to study nitrogen chemistry in this forested environment. Measured HONO mixing ratios show a diurnal pattern with minimum levels of $\sim 20$ 30 pptv during the day and maximum levels of $\sim 60-70 \mathrm{pptv}$ at night, which is significantly different from the results at other forested sites in Eastern US and Europe. The daytime HONO levels at Blodgett Forest are significantly lower compared to the other forested sites where minimum HONO levels during the day and maximum levels at night were often observed. This different diurnal pattern may be related to the unique diurnal wind pattern (i.e., upslope wind during the day and downslope wind at night), dry climatology, and low acid precipitation at Blodgett Forest. Intercomparison of HONO measurements by two different techniques, wet chemistry and CIMS, shows very good agreement, indicating reliable HONO measurements by both instruments. Although HONO only accounted for only $3 \%$ of total $\mathrm{NO}_{\mathrm{y}}$ on average, a strong HONO production rate $\left(1.59{\mathrm{ppbv} d a y^{-1}}^{-1}\right.$ existed in this environment, indicating a fast cycling from other forms of $\mathrm{NO}_{\mathrm{y}}$ to $\mathrm{HONO}$.

Because of relatively low mixing ratios of $\mathrm{HONO}$ in this environment, the photolysis of HONO did not contribute significantly to $\mathrm{HO}_{\mathrm{x}}$ production during this study. This is quite different from some studies in other forested areas, where HONO photolysis was typically found to be a dominant or at least an important $\mathrm{HO}_{\mathrm{x}}$ source. Further studies on $\mathrm{HONO}$ seasonal variations and HONO vertical fluxes are needed in order to improve our understanding of atmospheric oxidation and nitrogen budget in this kind of water-limited and anthropogenic pollution influenced environment with high biogenic emissions.

Acknowledgements. The authors would like to thank Sierra Pacific Industries for the use of their land and the University of California, Berkeley, Center for Forestry, Blodgett Forest Research Station for cooperation in facilitating this study. The authors also thank other research groups participating in this field study for the use of their data in the analysis. This study was partially supported by a National Science Foundation grant (ATM-0914619).

Edited by: J. Lelieveld

\section{References}

Acker, K., Febo, A., Trick, S., Perrino, C., Bruno, P., Wiesen, P., Möller, D., Wieprecht, W., Auel, R., Giusto, M., Geyer, A., Platt, U., and Allegrini, I.: Nitrous acid in the urban area of Rome, Atmos. Environ., 40, 3123-3133, 2006a.

Acker, K., Möller, D., Wieprecht, W., Meixner, F. X., Bohn, B., Gilge, S., Plass-Dülmer, C., and Berresheim, H.: Strong production of $\mathrm{OH}$ from $\mathrm{HNO}_{2}$ at a rural mountain site, Geophys. Res. Lett., 33, L02809, doi:10.1029/2005GL024643, 2006b.

Acker, K. and Möller, D.: Atmospheric variation of nitrous acid at different sites in Europe, Environ. Chem., 4, 242-255, 2007.

Alicke, B., Geyer, A., Hofzumahaus, A., Holland, F., Konrad, S., Pätz, H. W., Schäfer, J., Stutz, J., Volz-Thomas, A., and Platt, U.: $\mathrm{OH}$ formation by HONO photolysis during the BERLIOZ experiment, J. Geophys. Res., 108, 8247, doi:10.1029/2001JD000579, 2003.

Allegrini, I., Cortiello, M., Febo, A., and Perrino, C.: Generation of standard atmospheres of nitrous acid, In Physico-Chemical Behaviour of Atmospheric Pollutants, Kluwer Academic Publishers, Dodrecht, 140-144, 1990.

Ammann, M., Kalberer, M., Jost, D. T., Tobler, L., Rössler, E., Piguet, D., Gäggeler, H. W., and Baltensperger, U.: Heterogeneous production of nitrous acid on soot in polluted air masses, Nature, 395, 157-160, 1998.

Appel, B. R., Winer, A. M., Tokiwa, Y., and Biermann, H. W.: Comparison of atmospheric nitrous acid measurements by annular denuder and optical absorption systems, Atmos. Environ., 24A, 611-616, 1990.

Arens, F., Gutzwiller, L., Baltensperger, U., Gäggeler, H. W., and Ammann, M.: Heterogeneous reaction of $\mathrm{NO}_{2}$ on diesel soot particles, Environ. Sci. Technol., 35, 2191-2199, 2001.

Aubin, D. G. and Abbatt, J. P. D.: Interaction of $\mathrm{NO}_{2}$ with hydrocarbon soot: Focus on HONO yield, surface modification, and mechanism, J. Phys. Chem. A, 111, 6263-6273, 2007.

Beine, H. J., Amoroso, A., Dominé, F., King, M. D., Nardino, M., Ianniello, A., and France, J. L.: Surprisingly small HONO emissions from snow surfaces at Browning Pass, Antarctica, Atmos. Chem. Phys., 6, 2569-2580, doi:10.5194/acp-6-2569-2006, 2006.

Bejan, I., Abd-el-Aal, Y., Barnes, I., Benter, T., Bohn, B., Wiesen, P., and Kleffmann, J.: The photolysis of ortho-nitrophenols: a new gas phase source of HONO, Phys. Chem. Chem. Phys., 8, 2028-2035, 2006.

Bouvier-Brown, N. C., Goldstein, A. H., Gilman, J. B., Kuster, W. C., and de Gouw, J. A.: In-situ ambient quantification of monoterpenes, sesquiterpenes, and related oxygenated compounds during BEARPEX 2007: implications for gas- and particle-phase chemistry, Atmos. Chem. Phys., 9, 5505-5518, doi:10.5194/acp-9-5505-2009, 2009.

Bröske, R., Kleffmann, J., and Wiesen, P.: Heterogeneous conversion of NO2 on secondary organic aerosol surfaces: A possible source of nitrous acid (HONO) in the atmosphere?, Atmos. Chem. Phys., 3, 469-474, doi:10.5194/acp-3-469-2003, 2003. 
Carr, S., Heard, D. E., and Blitz, M. A.: Comment on "Atmospheric hydroxyl radical production from electronically excited $\mathrm{NO}_{2}$ and $\mathrm{H}_{2} \mathrm{O}$ ”, Science, 324, 5925, doi:10.1126/science.1166669, 2009.

Crounse, J. D., McKinney, K. A., Kwan, A. J., and Wennberg, P. O.: Measurement of gas-phase hydroperoxides by chemical ionization mass spectrometry, Anal. Chem., 78, 6726-6732, 2006.

Day, D. A., Farmer, D. K., Goldstein, A. H., Wooldridge, P. J., Minejima, C., and Cohen, R. C.: Observations of $\mathrm{NO}_{\mathrm{x}}$, SPNs, SANs, and $\mathrm{HNO}_{3}$ at a Rural Site in the California Sierra Nevada Mountains: summertime diurnal cycles, Atmos. Chem. Phys., 9, 4879-4896, doi:10.5194/acp-9-4879-2009, 2009.

Elshorbany, Y. F., Kurtenbach, R., Wiesen, P., Lissi, E., Rubio, M., Villena, G., Gramsch, E., Rickard, A. R., Pilling, M. J., and Kleffmann, J.: Oxidation capacity of the city air of Santiago, Chile, Atmos. Chem. Phys., 9, 2257-2273, doi:10.5194/acp-92257-2009, 2009.

Faloona, I. C., Tan, D., Lesher, R. L., Hazen, N. L., Frame, C. L., Simpas, J. B., Harder, H., Martinez, M., Di Carlo, P., Ren, X., and Brune, W. H.: A laser-induced fluorescence instrument for detecting tropospheric $\mathrm{OH}$ and $\mathrm{HO}_{2}$ : Characteristics and calibration, J. Atmos. Chem., 47, 139-167, 2004.

Farmer, D. K. and Cohen, R. C.: Observations of $\mathrm{HNO}_{3}$, SAN, $\mathrm{SPN}$ and $\mathrm{NO}_{2}$ fluxes: evidence for rapid $\mathrm{HOx}$ chemistry within a pine forest canopy, Atmos. Chem. Phys., 8, 3899-3917, doi:10.5194/acp-8-3899-2008, 2008.

Febo, A., Perrino, C., Gherardi, M., and Sparapani, R.: Evaluation of a high-purity and high-stability continuous generation system for nitrous acid, Environ. Sci. Technol., 29, 2390-2395, 1995.

Febo, A., Perrino, C., and Allegrini, I.: Measurement of nitrous acid in Milan, Italy, by DOAS and diffusion denuders, Atmos. Environ., 30, 3599-3609, 1996.

Fenn, M. E., Huntington, T. G., McLaughlin, S. B., Eagar, C., Gomez, A., and Cook, R. B.: Status of soil acidification of North America, J. Forest Sci., 52, Special Issue, 3-13, 2006.

Finlayson-Pitts, B. J., Wingen, L. M., Sumner, A. L., Syomin, D., and Ramazan, K. A.: The heterogeneous hydrolysis of $\mathrm{NO}_{2}$ in laboratory systems and in outdoor and indoor atmospheres: An integrated mechanism, Phys. Chem. Chem. Phys., 5, 223-242, 2003.

George, C., Strekowski, R. S., Kleffmann, J., Stemmler, K., and Ammann, M.: Photoenhanced uptake of gaseous $\mathrm{NO}_{2}$ on solid organic compounds: A photochemical source of HONO, Faraday Discuss., 130, 195-210, 2005.

Goldstein, A. H., Hultman, N. E., Fracheboud, J. M., Bauer, M. R., Panek, J. A., Xu, M., Qi, Y., Guenther, A. B., and Baugh, W.: Effects of climate variability on the carbon dioxide, water, and sensible heat fluxes above a ponderosa pine plantation in the Sierra Nevada (CA), Agr. Forest Meteorol., 101, 113-129, 2000.

Harrison, R. M., Peak, J. D., and Collins, G. M.: Tropospheric cycle of nitrous acid, J. Geophys. Res., 101, 14429-14439, 1996.

Heland, J., Kleffmann, J., Kurtenbach, R., and Wiesen, P.: A new instrument to measure gaseous nitrous acid (HONO) in the atmosphere, Environ. Sci. Technol., 35, 3207-3212, 2001.

Hirokawa, J., Kato, T., and Mafuné, F.: In situ measurements of atmospheric nitrous acid by chemical ionization mass spectrometry using chloride ion transfer reactions, Anal. Chem., 81, 83808386, 2009.

Honrath, R. E., Lu, Y., Peterson, M. C., Dibb, J. E., Arsenault, M. A., Cullen, N. J., and Steffen, K.: Vertical fluxes of $\mathrm{NO}_{\mathrm{x}}$, HONO, and $\mathrm{HNO}_{3}$ above the snowpack at Summit, Greenland, Atmos. Environ., 36, 2629-2640, 2002.

Huang, G., Zhou, X., Deng, G., Qiao, H., and Civerolo, K.: Measurements of atmospheric nitrous acid and nitric acid, Atmos. Environ., 36, 2225-2235, 2002.

Kleffmann, J., Kurtenbach, R., Lörzer, J. C., Wiesen, P., Kalthoff, N., Vogel, B., and Vogel, H.: Measured and simulated vertical profiles of nitrous acid. Part I: Field measurements, Atmos. Environ., 37, 2949-2955, 2003.

Kleffmann, J., Gavriloaiei, T., Hofzumahaus, A., Holland F., Koppmann, R., Rupp, L., Schlosser, E., Siese, M., and Wahner, A.: Daytime formation of nitrous acid: a major source of $\mathrm{OH}$ radicals in a forest. Geophys. Res. Lett., 32, L05818, doi:10.1029/2005GL022524, 2005.

Kleffmann, J., Lörzer, J. C., Weisen, P., Kern, C., Trick, S., Volamer, R., Rodenas, M., and Wirtz, K.: Intercomparison of the DOAS and LOPAP techniques for the detection of nitrous acid (HONO), Atmos. Environ., 40, 3640-3652, 2006.

Kleffmann, J. and Wiesen, P.: Technical Note: Quantification of interferences of wet chemical HONO LOPAP measurements under simulated polar conditions, Atmos. Chem. Phys., 8, 6813-6822, doi:10.5194/acp-8-6813-2008, 2008.

LaFranchi, B. W., Wolfe, G. M., Thornton, J. A., Harrold, S. A., Browne, E. C., Min, K. E., Wooldridge, P. J., Gilman, J. B., Kuster, W. C., Goldan, P. D., de Gouw, J. A., McKay, M., Goldstein, A. H., Ren, X., Mao, J., and Cohen, R. C.: Closing the peroxy acetyl nitrate budget: observations of acyl peroxy nitrates (PAN, PPN, and MPAN) during BEARPEX 2007, Atmos. Chem. Phys., 9, 7623-7641, doi:10.5194/acp-9-7623-2009, 2009.

Langridge, J. M., Gustafsson, R. J., Griffiths, P. T., Cox, R. A., Lambert, R. M., and Jones, R. L.: Solar driven nitrous acid formation on building material surfaces containing titanium dioxide: A concern for air quality in urban areas? Atmos. Environ., 43, 5128-5131, 2009.

Li, S., Mathews, J., and Sinha, A.: Atmospheric hydroxyl radical production from electronically excited $\mathrm{NO}_{2}$ and $\mathrm{H}_{2} \mathrm{O}$, Science, 319, 1657-1660, 2008.

Mao, J., Ren, X., Chen, S., Brune, W. H., Chen, Z., Martinez, M., Harder, H., Lefer, B., Rappenglück, B., Flynn, J., and Leuchner, M.: Atmospheric oxidation capacity in the summer of Houston 2006: Comparison with summer measurements in other metropolitan studies, Atmos. Environ., doi:10.1016/j.atmosenv.2009.01.013, in press, 2010.

Menz, F. C. and Seip, H. M.: Acid rain in Europe and the United States: an update, Environ. Sci. Policy, 7, 253-265, 2004.

Murphy, J. G., Day, D. A., Cleary, P. A., Wooldridge, P. J., and Cohen, R. C.: Observations of the diurnal and seasonal trends in nitrogen oxides in the western Sierra Nevada, Atmos. Chem. Phys., 6, 5321-5338, doi:10.5194/acp-6-5321-2006, 2006.

Ndour, M., D’Anna, B., George, C., Ka, O., Balkanski, Y., Kleffmann, J., Stemmler, K., and Ammann, M.: Photoenhanced uptake of NO2 on mineral dust: Laboratory experiments and model simulations, Geophys. Res. Lett., 35, L05812, doi:10.1029/2007GL032006, 2008.

Neftel, A., Blatter, A., Hesterberg, R., and Staffelbach, Th.: Measurements of concentration gradients of $\mathrm{HNO}_{2}$ and $\mathrm{HNO}_{3}$ over a semi-natural ecosystem, Atmos. Environ., 30, 3017-3025, 1996.

Park, J. -Y. and Lee, Y. -N.: Solubility and decomposition kinetics of nitrous acid in aqueous solution, J. Phys. Chem., 92, 6294- 
6302, 1988.

Pérez, I. M., Wooldridge, P. J., and Cohen, R. C.: Laboratory evaluation of a novel thermal dissociation chemiluminescence method for in situ detection of nitrous acid, Atmos. Environ., 41, 39934001, 2007.

Qin, M., Xie, P., Su, H., Gu, J., Peng, F., Li, S., Zeng, L., Liu, J., Liu, W., and Zhang, Y.: An observational study of the HONO- $\mathrm{NO}_{2}$ coupling at an urban site in Guangzhou City, South China, Atmos. Environ., 43, 5731-5742, doi:10.1016/j.atmosenv.2009.08.017, 2009.

Ren, X., Harder, H., Martinez, M., Lesher, R. L., Oliger, A., Simpas, J. B., Brune, W. H., Schwab, J. J., Demerjian, K. L., He, Y., Zhou, X., and Gao, H.: $\mathrm{OH}$ and $\mathrm{HO}_{2}$ chemistry in the urban atmosphere of New York City, Atmos. Environ., 37, 3639-3651, 2003.

Ren, X., Brune, W. H., Oliger, A., Metcalf, A. R., Simpas, J. B., Shirley, T., Schwab, J. J., Bai, C., Roychowdhury, U., Li, Y., Cai, C., Demerjian, K. L., He, Y., Zhou, X., Gao, $\mathrm{H}$., and Hou, J.: $\mathrm{OH}, \mathrm{HO}_{2}$ and $\mathrm{OH}$ Reactivity during the PMTACS-NY Whiteface Mountain 2002 Campaign: Observations and Model Comparison, J. Geophys. Res., 111, D10S03, doi:10.1029/2005JD006126, 2006.

Schartz, S. E. and White, W. H.: Solubility equilibria of the nitrogen oxides and oxyacids in dilute aqueous solution, Adv. Environ. Sci. Eng., 1-45, 1981.

Staffelbach, T., Neftel, A., and Horowitz, L. W.: Photochemical oxidant formation over southern Switzerland 2. Model results, J. Geophys. Res., 102, 23363-23373, 1997.

Stemmler, K., Ammann, M., Dondors, C., Kleffmann, J., and George, C.: Photosensitized reduction of nitrogen dioxide on humic acid as a source of nitrous acid, Nature, 440, 195-198, 2006.

Stockwell, W. R., Kirchner, F., and Kuhn, M.: A new mechanism for regional atmospheric chemistry modeling, J. Geophys. Res., 102, 25847-25879, 1997.

Stutz, J., Oha, H. -J., Whitlow, S. I., Anderson, C., Dibb, J. E., Flynn, J. H., Rappenglück, B., and Lefer, B.: Simultaneous DOAS and mist-chamber IC measurements of HONO in Houston, TX, Atmos. Environ., doi:10.1016/j.atmosenv.2009.02.003, in press, 2010.

Thomas, S., Ren, X., Stutz, J., Dibb, J., Zheng, J., Wood, E., and Rappenglck, B: Intercomparison of nitrous acid measurement methods during SHARP in Houston, TX, in preparation, 2010.

Thornton, J. A., Wooldridge, P. J., and Cohen, R. C.: Atmospheric $\mathrm{NO}_{2}$ : In situ laser-induced fluorescence detection at parts per trillion mixing ratios, Anal. Chem., 72, 528-539, 2000.
Vogel, B., Vogel, H., Kleffmann, J., and Kurtenbach, R.: Measured and simulated vertical profiles of nitrous acid, Part II-model simulations and indications for a photolytic source, Atmos. Environ., 37, 2957-2966, 2003.

Winer, A. M. and Biermann, H. W.: Long pathlength differential optical absorption spectroscopy (DOAS) measurements of gaseous $\mathrm{HONO}, \mathrm{NO}_{2}$ and $\mathrm{HCHO}$ in the California South Coast Air Basin, Res. Chem. Intermed., 20, 423-445, 1994.

Wolfe, G. M., Thornton, J. A., Yatavelli, R. L. N., McKay, M., Goldstein, A. H., LaFranchi, B., Min, K.-E., and Cohen, R. C.: Eddy covariance fluxes of acyl peroxy nitrates (PAN, PPN and MPAN) above a Ponderosa pine forest, Atmos. Chem. Phys., 9, 615-634, doi:10.5194/acp-9-615-2009, 2009.

Yokelson, R. J., Crounse, J. D., DeCarlo, P. F., Karl, T., Urbanski, S., Atlas, E., Campos, T., Shinozuka, Y., Kapustin, V., Clarke, A. D., Weinheimer, A., Knapp, D. J., Montzka, D. D., Holloway, J., Weibring, P., Flocke, F., Zheng, W., Toohey, D., Wennberg, P. O., Wiedinmyer, C., Mauldin, L., Fried, A., Richter, D., Walega, J., Jimenez, J. L., Adachi, K., Buseck, P. R., Hall, S. R., and Shetter, R.: Emissions from biomass burning in the Yucatan, Atmos. Chem. Phys., 9, 5785-5812, doi:10.5194/acp-9-5785-2009, 2009.

Zhou, X., Beine, H. J., Honrath, R. E., Fuentes, J. D., Simpson, W., Shepson, P. B., and Bottenheim, J. W.: Snowpack photochemical production of HONO: A major source $\mathrm{OH}$ in the Arctic boundary layer in springtime, Geophys. Res. Lett., 28, 4087-4090, 2001.

Zhou, X., Civerolo, K., Dai, H., Huang, G., Schwab, J., and Demerjian, K.: Summertime nitrous acid chemistry in the atmospheric boundary layer at a rural site in New York State, J. Geophys. Res., 107, 4590, doi:10.1029/2001JD001539, 2002a.

Zhou, X., He, Y., Huang, G., Thornberry, T. D., Carroll, M. A., and Bertman, S. B.: Photochemical production of nitrous acid on glass sample manifold surface, Geophys. Res. Lett., 29, 1681, doi:10.1029/2002GL015080, 2002b.

Zhou, X., Gao, H., He, Y., Huang, G., Bertman, S., Civerolo, K., and Schwab, J.: Nitric acid photolysis on surfaces in low-NOx environments: significant atmospheric implications, Geophys. Res. Lett., 30, 2217, doi:10.1029/2003GL018620, 2003.

Zhou, X., Huang, G., Civerolo, K., Roychowdhury, U., and Demerjian, K. L.: Summertime observations of $\mathrm{HONO}, \mathrm{HCHO}$, and $\mathrm{O}_{3}$ at the summit of Whiteface Mountain, New York, J. Geophys. Res., 112, D08311, doi:10.1029/2006JD007256, 2007.

Ziemba, L. D., Dibb, J. E., Griffin, R. J., Anderson, C. H., Whitlow, S. I., Lefer, B. L., Rappenglück, B., and Flynn, J.: Heterogeneous conversion of nitric acid to nitrous acid on the surface of primary organic aerosol in an urban atmosphere, Atmos. Environ., doi:10.1016/j.atmosenv.2008.12.024, in press, 2010. 